\title{
Kontroversi Terapi Homeopati Untuk Sembuhkan Berbagai Penyakit
}

\author{
Elmira Rachma \\ Program Studi Sarjana Farmasi, Fakultas Farmasi, Universitas Padjadjaran, Sumedang, 45363 \\ email: ameiliaaaa4@gmail.com
}

\begin{abstract}
Abstrak :
Terapi homoepati kurang didengar di masyarakat Indonesia dikarenakan di Indonesia jarang dipakai pengobatan secara homoepati. Penyembuhan penyakit secara homoepati sangat dimungkinkan untuk masyarakat Indonesia, dikarenakan penyembuhan secara homoepati dapat memanfaatkan tumbuhan yang ada di indonesia. Hoemoepati sering disebut dengan gagasan "seperti pengobatan", penyakit yang disembuhkan contohnya penyakit demam. Mengobati penyakit demam dengan cara mengambil ekstrak tanaman yang bisa menurunkan demam, walaupun ketingkatan yang sangat encer. Pengobatan homoepati tidak memenuhi persyaratan yang ada di farmokologi modern. Pengobatan homoepati memang tidak memakai percobaan pada binatang namun bahan percobaan langsung ke manusia, hal itu tidak diketahui efek toksik yang mungkin terkandung dalam obat tersebut. Tetapi pengobatan homoepati ini bisa dicontoh pada perlakuan terhadap pasien yang meyakinkan untuk sembuh. Oleh karena itu, pilihlah penyembuhan yang sudah di rekomendasi oleh peneliti-peneliti.
\end{abstract}

Keyword : terapi homeopati, penyakit, pengobatan

\section{Outline}

- Pendahuluan

- Kontroversi teknik homeopati

- Homoepati di mata dunia

- Kasus Pengobatan Homoepati

\section{Pendahuluan}

Homoepati merupakan pengobatan secara alternatif yang sudah terkenal di dunia. Homoepati berasal dari negara Eropa yang ditemukan sejak abad kedelapan belas oleh Samuel Hahnemann.

Teori dasar di balik homeopati adalah bahwa orang sakit dapat disembuhkan dengan menggunakan efek pantulan substansi yang menghasilkan gejala sakit pada orang sehat. Homeopati dipersiapkan dengan menambahkan banyak air dalam suatu substansi, mengocoknya, lalu mengambil sedikit air, menambahkannya ke banyak air, mengocoknya, dan proses ini diulang-ulang hingga 200 kali dalam beberapa pengobatan. Hahnmemann mengatakan ini akan mengeluarkan "kekuatan penyembuh yang ada pada obat". 
Zat yang terkandung dalam obat ini yaitu hewan, mineral, dan juga herbal. Pembuatan obat alternatif ini sangat unik dengan cara mengencerkan bahan baku dengan cara pelarut alkohol atau eksepien yang lainnya dan potensi produk ke dalam kelas yang berbeda. Pengenceran obat alternatif ini sangatlah tinggi sehingga tidak ditemukan satu molekul dari bahan baku asli.

\section{Kontroversi teknik homeopati}

Pengenceran obat alternatif itulah banyak perdebatan, ada yang percaya pada pengobatan alternatif itu sehingga penyakit yang diderita sembuh dan juga ada yang membantah pengobatan alternatif tersebut dikarenakan tidak sesuai dengan persyaratan yang ada di farmakologi modern. (WHO, 2009)

Hoemoepati sering disebut dengan gagasan "seperti pengobatan", penyakit yang disembuhkan contohnya penyakit demam. Mengobati penyakit demam dengan cara mengambil ekstrak tanaman yang bisa menurunkan demam, walaupun ketingkatan yang sangat encer.

Pengobatan homoepati ini kebanyakan sangat encer sehingga tidak tahu zat asli yang berada di dalamnya. Pil yang di gunakan pada pengobatan homoepati bekerja karena air namun terdapat zat lain yang tidak diketahui sebelum diencerkan.

Para ilmiah tidak menerima teori tersebut karena cenderung memiliki efek plasebo, dikarenakan setiap tetes minuman. Para peniliti menyatakan bahwa homeopati tidak berpengaruh pada kesehatan di dalam tubuh manusia (Nield, 2018)

Terdapat keuntungan pengobatan homoepati diantaranya yaitu pertama jika seseorang mengeluh yang dideritanya maka pengobatan homoepati langsung menyembuhkan tanpa memasuki tes laboratorium. Kedua kandungan obat yang terdapat pada obat homoepati merupakan bahan alami sehingga tidak ada efek samping pada tubuh manusia, jika obat kimia terdapat efek samping yang memungkinkan memperparah kondisi pasien. Ketiga obat homoepati mempunyai prinsip bahwa pasien harus sembuh total sehingga pasien tidak bergantungan pada obat. Keempat obat homoepati berprinsip bahwa obat untuk menghilangkan penyebab dari penyakit, tidak menghilangkan akibat dari penyakit.

Kelima obat homoepati digunakan untuk menghilangkan gejala yang ada di tubuh manusia dari fisik ataupun psikis. Keenam obat homoepati dapat digunakan oleh semua kalangan masyarakat, bisa dengan balita, anak kecil, orang dewasa, manula, ataupun ibu hamil, karena obat homoepati aman digunakan. Ketujuh obat homoepati disenangi oleh anak-anak karena rasanya yang manis dan juga enak di lidah. Kedelapan obat homoepati tidak memakai bahan percobaan seperti tikus, mecit, ataupun kelinci.

\section{Homoepati di mata dunia}

Tidak hanya negara Eropa yang sudah memakai pengobatan alternatif homoepati, beberapa negara juga sudah memakai obat alternatif ini sebagai penyembuhan penyakit, negara yang memakai penyembuhan homoepati diantaranya yaitu negara Asia Selatan, Amerika Utara, dan juga Amerika Selatan. 
Pada pasar global pengobatan homoepati sangat sukses, pendapat yang akan di dapat pada industri obat homoepati mencapai US \$ 17 miliar pada tahun 2024.

Peningkatan pengobatan homoepati sangatlah meningkat. Perluasan pasar secara global tentang keamanan dan kualitas obat homoepati menjadi perhatian oleh bidang kesehatan, industri farmasi, dan juga konsumen. Keamanan yang terdapat pada obat homoepati berkualitas bagus karena pengelolaan kualitas obat lebih sederhana daripada kualitas obat kimia.

Gabungan yang terdapat pada homoepati sangatlah sederhana. Kualitas obat homeopati lebih baik baik karena kualitas prosedur yang dipakai pada produksi obat dan juga bahan bakunya yang baik. Produk obat yang aman dipakai untuk manusia dapat memenuhi standar kualitas tinggi, obat homepati diarahkan menjadi produk obat yang aman agar bisa digunakan oleh masyarakat banyak. (WHO, 2009).

Pasar globalisasi membuat homeopati menjadi terkenal, disebabkan banyak bahan baku dan obat-obatan bisa diambil dari negara manapun. Seperti di daerah Lombardy, masyarakat yang menggunakan pengobat homoepati secara rutin sebanyak $20 \%$, masyarakat yang hanya menggunakan secera sesekali sebanyak $60 \%$, sedangkan masyarakat untuk menyembuhkan penyakit dengan cara pengobatan homoepati sebanyak 34\%, dari data tersebut masyarakat Lombardy memulai meyembuhkan penyakit dengan cara pengobatan homoepati. Menurut masyarakat Lombardy, pengobatan homoepati menjamin kualitasnya yang tinggi dan keamanannya (WHO, 2009).

\section{Kasus Pengobatan Homoepati}

Sudah terdapat beberapa kasus tentang pengobatan homoepati, terdapat ayah dan anak yang ditangkap sebagai dokter palsu. Ayah dan anak tersebut bernama Ashim dan Aradeep Chatterjee, mereka membuat jurnal tentang pengobatan alternatif. Ashim dan Aradeep Chatterjee berasal dari negara India.

Bapak dan Anaknya mempunyai klinik sendiri yang bernama the Critical Cancer Management Research Centre and Clinic (CCMRCC) di kolkata. Ashim merupakan praktisi homoepati dan Aradeep Chatterje merupakan. Alasan Ashim dan Aradeep Chatterje ditangkap karena mereka menjalan klinik mereka tanpa memegang kualifikasi medis yang dibutuhkan, yang mereka tuntutan untuk memiliki.

Aradeep Chatterje mengaku menjadi pekerja MD di bidang onkologi intergratif, tetapi Aradeep tidak empunyai gelar medis. Ashim pun berperilaku begitu, dia tidak mempunyai gelar medis allopathic. Terapi Psorinum ini berasal dari ekstrak alkohol yang dari kudis, sel punca, dan juga sel-sel yang terdapat pada pusar. Menurut para periset ekstrak alkohol yang berasal dari kudis, sel punca, dan juga sel-sel pada pusar, dapat mengakibatkan sel kekebalan tubuh aktif seperti makrofag dan juga membuat respons imun anti tumor yang kompleks menjadi aktif. Namun percobaan ini harus matangmatang dipersiapkan dengan cara menipiskan satu bagian pada sepuluh total enam kali atau sebanding dengan satu bagian pada sejuta. 
IImu yang ditemukan oleh Ashim dan Aradeep Chatterjee sedikit dipertanyakan. Pencabutan publikasi di jurnal Ashim dan Aradeep Chatterje dicabut oleh editor Evidence-Based Complementary and Alternative Medicine, alasan pencabutan itu karena dikhawatirkan tentang etika, pengarang, kualitas pelaporan, dan kesimpulan yang akan menyesatkan. Kepala editor mengkhawatirkan bahwa penelitian sudah disetujui sejak tahun 2001 namun klinik yang dipunyai oleh Ashim dan Aradeep Chatterjee didirikan pada tahun 2008.

Saat diminta klarifikasi Aradeep Chatterjee tidak menjawab, tetapi rekan yang ikut menulis jurnal tersebut tidak ingin di tulis namanya dan tidak sadar bahwa isi jurnal tersebut tentang penelitian itu. Seharusnya peneliti-peniliti ini sudah ditangkap sebelum tahun 2011.

Pada uji coba psorinum, peserta belum pernah mencoba pengobatan kanker konvensional. Penyediaan perawatan di klinik Chatterjes masih dipertanyakan dan juga jurnal yang dibuat oleh Chatterjes masih belum bisa dipublikasikan. Jurnal Chatterjes bisa dipublikasikan karena peer review tidak memadai dan tanggung jawab yang harus disama ratakan pada jurnal itu sendiri

Dengan demikian, pengobatan homoepati tidak memenuhi persyaratan yang ada di farmokologi modern. Pengobatan homoepati memang tidak memakai percobaan pada binatang namun bahan percobaan langsung ke manusia, hal itu tidak diketahui efek toksik yang mungkin terkandung dalam obat tersebut. Tetapi pengobatan homoepati ini bisa dicontoh pada perlakuan terhadap pasien yang meyakinkan untuk sembuh. Pilihlah penyembuhan yang sudah di rekomendasi oleh peneliti-peniliti.

\section{Daftar pustaka :}

Dockrill, Peter. 2018. Homeopathy paper on Pus Retracted after Alleged 'Fake Doctor' Authors Got Arrested. Diakses di https://www.sciencealert.com/homeopathy-paperblister-pus-retracted-alleged-fake-doctor-authors-arrested-chatterjees-psorinum. Diakses pada 17 Maret 2018

Nield, David. 2018. This Video Explains All You Need to Know About World's Most Popular Alternative Medicine. Diakses di https://www.sciencealert.com/everything-youneed-to-know-about-homeopathy-alternative-medicine. Diakses pada 16 Maret 2018

WHO. 2009. Safety issues in the preparation of homeopathic medicines. Diakses di http://www.who.int/medicines/areas/traditional/Homeopathy.pdf. Diakses pada 16 Maret 2018

Widiyani, Rosmha. 2013. Mengenal Pengobatan Homeopati. Diakses di https://lifestyle.kompas.com/read/2013/07/13/1343517/Mengenal.Pengobatan.Homeopati

. Diakses pada 16 Maret 2018 